\title{
Perilaku hidup bersih dan sehat pondok pesantren Al-Ishlahul Ma'arif pada masa new normal
}

\section{Dwi Kartika Risfianty ${ }^{1}$, Indrawati ${ }^{2 *}$, Farah Heniati Santosa ${ }^{3}$, Samsul Bahri ${ }^{4}$, Samsuriadi $^{5}$}

\author{
${ }^{1}$ Biologi, FMIPA, Universitas Nahdlatul Wathan Mataram, Mataram \\ 2,3,4,5Pendidikan Matematika, FKIP, Universitas Nahdlatul Wathan Mataram, Mataram
}

flowmath@gmail.com

\begin{abstract}
Covid-19 is a respiratory tract infection that is transmitted through coughing and sneezing. Covid-19 is characterized by the appearance of flu symptoms, cough, fever, respiratory problems and even death. The community in the Al-Ishlahul Ma'arif Islamic boarding school in Kediri, West Lombok, still looks unfamiliar with wearing masks when inside and outside the cottage environment. The purpose of this community service is to empower the community in using masks and implementing a clean and healthy lifestyle. The service method is in the form of donations of masks, vitamins and disinfectants as well as presentation on how to use them orally in addition to providing information related to clean and healthy living behavior in an effort to prevent COVID-19. The results of this service activity are providing information about the importance of implementing clean and healthy living behaviors and the service team providing masks, disinfectant liquid, disinfection equipment, and some vitamins to the administrators in the hope of making it easier for administrators to implement clean and healthy living behaviors to reduce the risk of spreading and transmission of the covid-19 virus in the Al-Ishlahul Ma'arif Islamic Boarding School, Kediri.
\end{abstract}

Keywords: clean behavior; healthy; covid-19

\begin{abstract}
Abstrak
Covid-19 merupakan penyakit infeksi pernafasan yang penularannya melalui percikan batuk dan bersin. Covid-19 ditandai dengan munculnya gejala flu, batuk, demam, gangguan pernafasan hingga kematian. Masyarakat di lingkungan pondok pesantren Al-Ishlahul Ma'arif Kediri Lombok Barat masih terlihat belum terbiasa menggunakan masker pada saat di dalam maupun di luar lingkungan pondok. Pegabdian ini bertujuan untuk memberdayakan masyarakat dalam penggunaan masker dan membiasakan pola hidup bersih dan sehat. Metode yang digunakan yakni berupa donasi masker, vitamin dan desinfektan serta pemaparan cara pemakaiannya secara lisan, selain itu memberikan informasi terkait perilaku hidup bersih dan sehat (PBHS) dalam upaya mencegah covid-19. Hasil dari kegiatan pengabdian ini yakni memberikan informasi tentang pentingnya menerapkan PBHS dan tim pengabdian memberikan masker, cairan desinfektan, alat desinfaksi, dan beberapa vitamin kepada para pengurus, dengan harapan memudahkan para pengurus pondok pesantren untuk menerapkan PBHS untuk mengurangi resiko penyebaran dan penularan virus covid-19 di lingkungan Pondok Pesantren Al-Ishlahul Ma'arif Kediri.
\end{abstract}

Kata Kunci: perilaku bersih; sehat, covid-19

\section{PENDAHULUAN}

Strain severe Acute Respiratory Syndrom Coronavirus 2 (SARS-CoV 2) atau yang saat ini dikenal dengan covid-19 merupakan penyakit yang menyerang pernafasan dengan gejala ringan hingga berat dan pertama kali ditemukan di Wuhan China pada akhir tahun 2019 (Mahendra, A U., et al 2020). Covid-19 ditandai dengan munculnya gejala 
flu, batuk, demam, gangguan pernafasan hingga kematian. Pada beberapa kasus, covid19 tidak memberikan gejala pada penderitanya (Nurfadillah, A R, 2020). Covid-19 dapat ditularkan melalui droplet dari seseorang yang menderita covid-19 pada saat bersin atau batuk (Sekeon, F M., Rumayar, A A., \& Tucunan, A A T, 2021).

Untuk memperlambat penyebaran virus covid-19, perlu dilakukan langkah-langkah pencegahan seperti, cuci tangan dengan sabun dan air mengalir selama 20 detik, menggunakan masker, menggunaan hand sanitizer, membersihkan barang-barang disekitar menggunakan antiseptik atau desinfektan, melakukan social distancing hingga mengurangi menyentuh area wajah ketika sudah bepergian. Selain menerapkan perilau hidup bersih, hidup sehat juga sangat dianjurkan pada masa pandemi covid-19 ini. Melakukan ativitas fisik seperti berolahraga dan makan makanan yang bergizi merupakan salah satu metode pencegahan covid-19 (Kemenkes, 2020). Tanggal 7 Maret 2020 ditetapkan sebagai tahap Tanggap Darurat untuk covid-19 oleh Presiden Republik Indonesia dan mengeluarkan keputusan presiden No. 7 Tahun 2020tentang Gugus Tugas Percepatan Penanganan Corona yang dikeluarkan oleh Badan Nasional Penanggulangan Bencana (BNPB) (Mailani, F., et al, 2020). Penderita covid-19 di provinsi Nusa Tenggara Barat hingga tanggal 14 April 2021 sebanyak 11.498 jiwa, sebanyak $1.070(9,31 \%)$ sedang dalam perawatan, sebanyan $9932(86,38 \%)$ dinyatakan sembuh dan sebanyak 496 jiwa (4,31\%) dinyatakan meninggal dunia (Germas NTB, 2021).

Pengetahuan masyarakat tentang pentingnya perilaku hidup bersih dan sehat terutama dilingkungan pondok pesantren perlu lebih ditingkatkan. Memasuki era New Normal saat ini, masyarakat mulai melakukan aktivitas perekonomian dan sosial seperti biasa. Tidak jarang selama melakukan kegiatan sehari-hari masyarakat mulai melupakan penggunaan masker ditengah kerumunan. Pengetahuan masyarakat tentang pentingnya perilaku hidup bersih dan sehat (PHBS) dan tentang pengetahuan tentang pentingnya menggunakan masker memiliki pengaruh penting tuntuk mengantisipasi terjadinya penularan (Marwang, S \& Sudirman, J, 2020). Para pengelola tempat umum, tempat kerja, tempat ibadah, sekolah dan pantiasuhan diharapkan mampu menerapka protokol kesehatan untuk memastikan masyarakat dapat beraktivitas kembali dan tetap aman dari covid-19.

Saat ini kita semua harus menjaga kebersihan dengan rajin mencuci tangan dengan air dan sabun untuk mencegah penularan covid-19. Berbagai jenis mikroorganisme seperti bakteri dan virus menempel pada tangan setiap hari selain itu dengan adanya kontak fisik dengan lingkungan, dapat menyebabkan berbagai penyakit seperti halnya penularan virus corona atau covid 19. Virus ini sangatlah berbahaya dan mematikan umat manusia jika tidak tertolong atau tidak dicegah dengan kesadaran kita sendiri. Salah satu cara yang dapat kita lakukan adalah dengan kita harus memakai masker dimanapun kita berada, menggunakan hand sanitizer atau mencuci tangan menggunakan sabun dan air mengalir, menjaga jarak dengan orang lain minimal 1 meter, dan menerapkan perilaku hidup bersih dan sehat. 
Para pelaksana pengabdian kepada masyarakat penting untuk melakukan komunikasi dan edukasi untuk meningkatkan pengetahuan dan pemahaman masyarakat. Oleh karena itu pengabdian masyarakat ini dilaksanakan dengan tujuan memberikan pengetahuan terkait bagaimana cara menerapkan perilaku hidup bersih dan sehat dalam kehidupan sehari-hari agar terhindar dari corona atau covid 19. Pengabdian Masyarakat ini dilakukan di Pondok Pesantren Al-Ishlahul Ma'arif Kediri Lombok Barat yang memiliki jumlah guru sebanyak 30 orang dan jumlah santri sebanya 88 orang, dimana 47 orang merupakan santri Madrasah Aliyah dan 41 orang merupakan santri Sekolah Menengah Pertama. Pondok Pesantren merupakan salah satu tempat yang rentan dalam penularan covid-19 dikarenakan Pondok Pesantren adalah tempat yang memiliki penghuni dalam jumlah besar. Maka dari itu, Fakultas Matematika dan Ilmu Pengetahuan Alam bersama dengan Fakultas Keguruan dan Ilmu Pendidikan Universitas Mataram tertarik untuk mengadakan pengabdian kepada masyarakat dengan memberikan informasi terkait bagaimana cara menerapkan pola hidup bersih dan sehat tanpa biaya dan tidak susah. Selain menyampaikan informasi terkait pola hidup bersih dan sehat, tim pengabdian juga membagikan masker, seperangkat alat dan bahan untuk desinfektan sehingga perilaku hidup bersih dan sehat bisa diterapkan dilingkungan Pondok Pesantren Al-Ishlahul Ma'arif Kediri sehingga bisa mengurangi kemungkinan penyebaran virus covid-19.

\section{METODE PELAKSANAAN}

Kegiatan Pengabdian kepada Masyarakat ini dilaksanakan untuk meningkatkan kesadaran masyarakat terkait pentingnya menerapkan dan menjaga perilaku hidup bersih dan sehat. Pengabdian di lakukan di Pondok Pesantren Al-Ishlahul Ma'arif Kediri, dengan subyek pengabdian adalah para pengurus dan para santri yang berada di lingkungan pondok pesantren. Metode pengabdian yang digunakan yaitu dengan melakukan pengarahan kepada para pengasuh Pesantren Al-Ishlahul Ma'arif Kediri tentang pentingnya menerapkan Perilaku Hidup Bersih dan Sehat (PHBS) pada area Pondok Pesantren dan ketaatan para pengasuh dan anak-anak asuh dalam menggunakan masker ketika berinteraksi di lingkungan Pondok Pesantren. Selama kegiatan pengabdian dilaksanakan, semua penyelenggara maupun peserta kegiatan menerapkan protokol kesehatan yang telah dicanangkan pemerintah yakni menggunakan masker dan melakukan social distancing selama melakukan pengarahan hingga penyerahan alat disinfaksi, desinfektan dan masker.

Langkah-langkah kegiatan pengabdian yang dilakukan adalah dengan memberi penjelasan mengenai manfaat hidup bersih dan sehat dan bagaimana cara menerapakan pola hidup bersih dan sehat dalam kehidupan sehari-hari dipondok pesantren. Hidup bersih dan sehat tidaklah memerlukan alat yang mahal, asalkan ada keinginan untuk berperilaku bersih dan kedisiplinan maka akan tercapai pola hidup yang bersih dan sehat. Menyampaikan informasi bahwa mencegah penyebaran virus dengan menjalankan kebiasaan perilaku hidup bersih dan sehat (PHBS) seperti rajin mencuci tangan, membersihkan toilet, makan makanan bergizi, berjemur saat pagi 
hari, meminum air putih yang cukup, berolah raga kurang lebih 30 menit setiap hari dan meminum vitamin atau jamu yang dapat meningkatkan imun tubuh.

\section{HASIL DAN PEMBAHASAN}

Semua masyarakat sekarang ini sedang panik karena virus corona sedang tersebar di Indonesia. Saat ini kita dituntut untuk menjaga kebersihan dan mengatur pola hidup agar hidup dengan bersih dan sehat. Sehingga imun tubuh menjadi kuat menghadapi segala jenis virus dan bakteri. Era New Normal ini banyak masyarakat yang masih menganggap bahwa menghindari penderita covid-19 merupakan cara terbaik untuk menghindari diri dari paparan viris covid-19. Covid-19 merupakan mikroorganisme yang dapat menempel pada benda mati dan dapat ditularkan melalui bersin atau batuk dalam jarak dekat. Penerapan protokol kesehatan dengan perilaku hidup bersih dan sehat serta menerapkan protokol 3M (mencuci tangan, menggunakan masker, menjaga jarak) merupakan salah satu cara pencegahan penularan penyakit covid-19. Kegiatan ini dilakukan untuk meningkatkan pemahaman dan pengetahuan mengenai upaya preventif masyarakat terhadap pandemi Covid-19 sekarang ini, yaitu dengan cara penggunaan masker, meminum vitamin, dan melakukan penyemprotan disenfektan, serta menerapkan perilaku hidup bersih dan sehat. Masyarakat perlu mendapatkan pemaparan ilmu pengetahuan baik secara langsung maupun tidak langsung. Ilmu pengetahuan yang disampaikan adalah berupa edukasi secara lisan. Pemaparan informasi mengenai prilku hidup bersih dan sehat yang dilakuan hanya terbatas pada para pengurus pondok pesantren saja, akibat adanya pandemi Covid-19 ini.

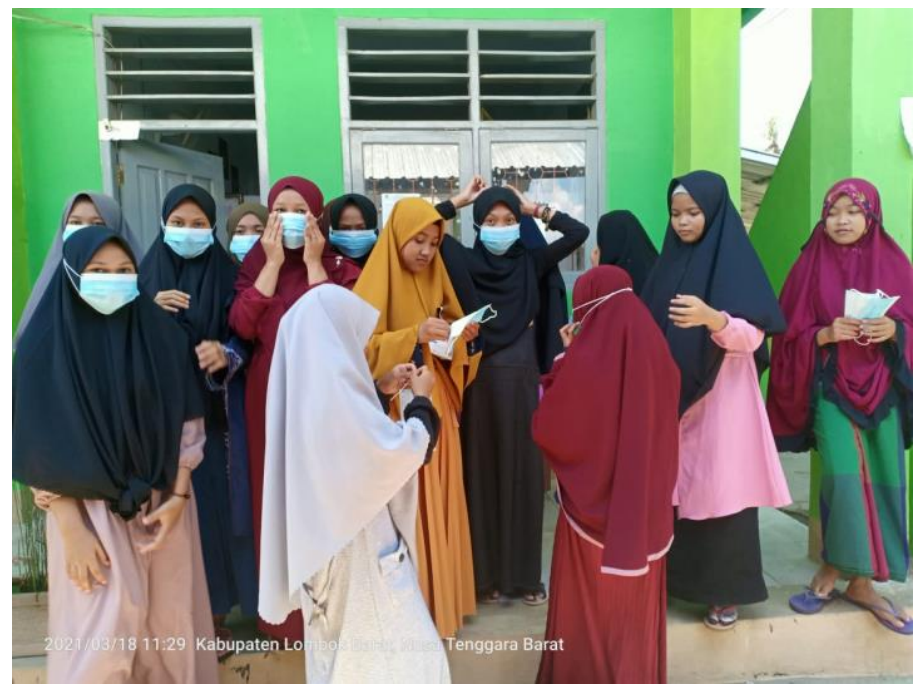

Gambar 2: Para Santri Pondok Pesantren Al-Ishlahul Ma'arif Kediri Menggunakan Masker yang diberikan

Di lingkungan Pondok Pesantren Al-Ishlahul Ma'arif Kediri Masker merupakan Alat Pelindung Diri (APD) yang saat ini wajib digunakan oleh pengghuninya jika melakukan kegiatan diluar pondok. Namun sayang masih banyak penghuni pondok yang 
melalaikan untuk menggunakan masker pada saat di dalam maupun diluar lingkungan pondok pesantren. Seyogyanya masker digunakan untuk melindungi area hidung dan mulut sehingga mengurangi resiko terkena droplet ketika berkomunikasi dengan orang lain. Oleh karena itu pada saat melakukan pengabdian terkait menyampaikan informasi mengenai Perilau Hidup Bersih dan Sehat, tim pengabdian juga memberikan masker kepada para santri di lingkungan Pondok Pesantren Al-Ishlahul Ma'arif Kediri. Gambar 1 menunjukkan bahwa para santri bahagia diberikan masker medis untuk digunakan selama berada dilingkungan pondok.

Selain memberikan masker, tim juga memberikan alat semprot disenfektan, cairan disenfektan untuk membersihkan lingkungan pondok pesantren (Gambar 2). Desinfektan merupakan salah satu cara untuk menerapkan perilau hidup bersih dan sehat dilingkungan Pesantren Al-Ishlahul Ma'arif Kediri. Desinfektan merupakan antiseptik yang digunakan untuk membersihkan benda-benda mati yang berada di lingkungan Pesantren Al-Ishlahul Ma'arif Kediri untuk mengurangi resiko terpapar oleh virus covid-19 (Charisma, A M., et al, 2020). Selain itu, tim juga memberikan beberapa vitamin yang dapat dikonsumsi untuk menguatkan imun tubuh para santri selama di pondok pesantren.

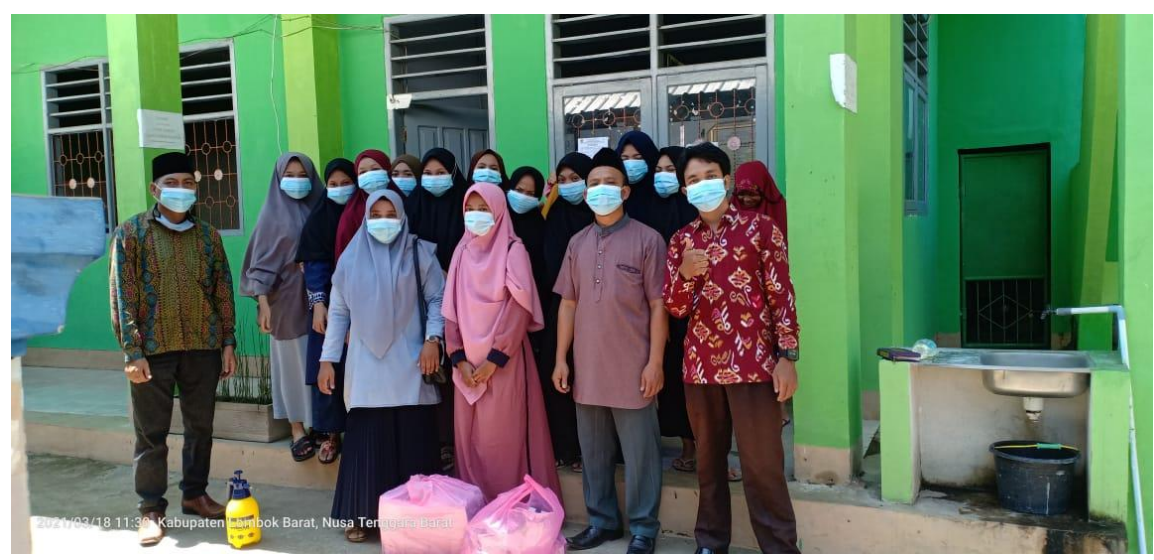

Gambar 2 : Penyerahan Masker, Desinfektan dan Vitamin kepada Pengurus Pondok Pesantren Al-Ishlahul Ma'arif Kediri

Penerapan 3M dan perilaku hidup bersih dan sehat (PHBS) dimasyarakat saat ini masih belum dilakukan dengan maksimal. Masyarakat mulai menganggap remeh protokol kesehatan dan meremehkan penyebaran covid-19. Selain memberikan pengetahuan tentang penerapan perilaku bersih dan sehat kepada para pengurus Pondok Pesantren Al-Ishlahul Ma'arif Kediri, kegiatan Pengabdian Masyarakat ini juga memberikan pengetahuan pentingnya perilaku hidup bersih dan sehat (PHBS) sebagaimana yang ditunjukkan oleh Gambar 3 kepada para pengurus di Pondok Pesantren Al-Ishlahul Ma'arif Kediri sehingga para pengurus dan santri mampu melakukan pencegahan secara mandiri terhadap penularan virus covid-19 baik dilingkungan pondok pesantren maupun diluar lingkungan pondok pesantren. Fokus edukasi yang dilakukan lebih kepada cara untuk mencegah penyebaran virus dengan 
menjalankan kebiasaan perilaku hidup bersih dan sehat (PHBS) seperti rajin mencuci tangan, membersihkan toilet, makan makanan bergizi, berjemur saat pagi hari, meminum air putih yang cukup, berolah raga kurang lebih 30 menit setiap hari dan meminum vitamin.

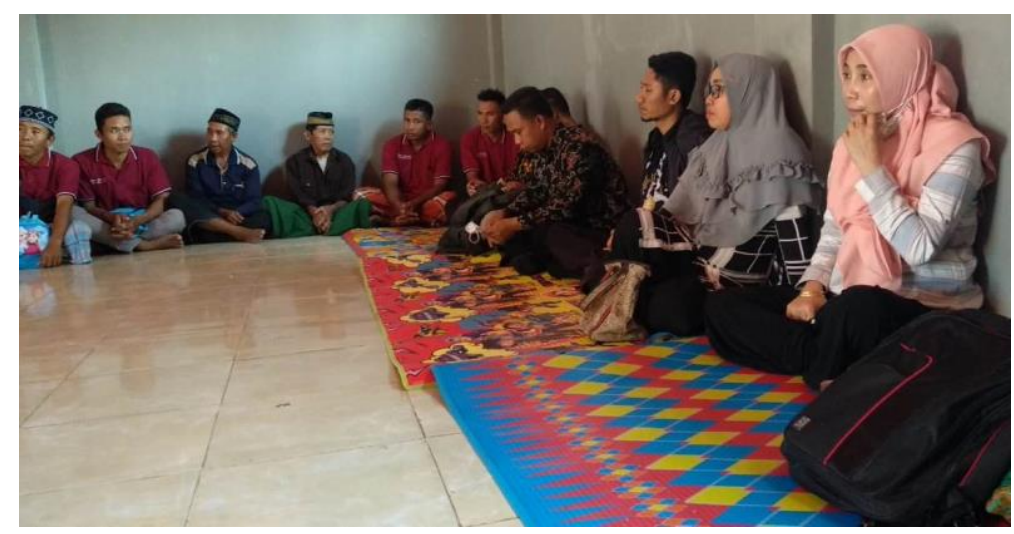

Gambar 3 : Penyampaian Informasi Terkait Perilaku Hidup Bersih Dan Sehat Kepada Pengurus Pondok Pesantren Al-Ishlahul Ma'arif Kediri

Perilaku hidup bersih dan sehat (PHBS) merupakan semua perilaku kesehatan yang dilakukan secara individual. Perilaku hidup bersih dan sehat (PHBS) bertujuan untuk meningkatkan kesadaran masyarakat dalam menjalankan hidup bersih dan sehat di era new normal saat ini. Perilaku hidup bersih dan sehat (PHBS) dan 3M merupakan langkah awal untuk mengurangi resiko penyebaran dan penularan virus covid-19. Gambar 3 menunjuukan kegiatan memperian informasi terkait perilaku hidup bersih dan sehat. Selain pemberian informasi tentang perilaku hidup bersih dan sehat (PHBS) dan 3M kepada pengasuh dan santri di Pondok Pesantren Al-Ishlahul Ma'arif Kediri, tim pengabdian masyarakat UNW Mataram juga memberikan informasi tentang website http://corona.ntbprov.go.id yang telah disiapkan oleh Pemerintah Nusa Tenggara Barat untuk membantu masyarakat Nusa Tenggara Barat mencari informasi tentang covid-19 di Nusa Tenggara Barat. Dengan mengunjungi website tersebut, masyarakat dapat mengetahui informasi tentang rumah sakit rujukan untuk penderita covid-19, informasi vasin covid-19 hingga mampu melakukan Self Check-Up untuk mengetahui kondisi tubuh secara individual tanpa perlu mengunjungi rumah sakit.

\section{SIMPULAN}

Kesimpulan dari kegiatan pengabdian ini yakni memberikan informasi tentang pentingnya menerapkan PBHS dan memberikan masker, cairan desinfektan, alat desinfaksi, dan beberapa vitamin kepada para pengurus dengan harapan memudahkan para pengurus Pondok Pesantren Al-Ishlahul Ma'arif Kediri untuk menerapkan perilaku hidup bersih dan sehat (PHBS) untuk mengurangi resiko penyebaran dan penularan virus covid-19 di lingkungan Pondok Pesantren tersebut. 


\section{UCAPAN TERIMA KASIH}

Ucapan terima kasih diberikan kepada penyandang dana kegiatan pengabdian yaitu Universitas Nahdlatul Wathan Mataram. Serta tak lupa ucapan terimakasih untuk para pengurus Pondok Pesantren Al-Ishlahul Ma'arif Kediri Lombok Barat yang mengizinkan tim untuk berkunjung dan pelaksanakan pengabdian sesuai dengan alur yang telah disepakati bersama.

\section{REKOMENDASI}

Kegiatan pengabdian ini sekiranya terus dilaksanakan khususnya untuk lokasi-lokasi atau tempat-tempat pendidikan dilaksanakan. Pelaksanaan pengabdian tidak tapat dilaksanakan secara maksimal karena keterbatasan waktu dan biaya. Selain itu informasi yang disampaikan adalah berupa edukasi secara lisan oleh karena keterbatasan kami dalam proses penyampaian terutama akibat adanya pandemi Covid19 ini. Sekiranya pelaksanaan selanjutnya dengan menyiapkan brosur atau pamphlet yang berisi mengenai informasi terkait perilaku hidup bersih dan sehat.

\section{REFERENSI}

Charisma, A M., et al. 2020. Implementasi Sadar Covid-19 berbasis Cipta Karya Masyarakat dalam PHBS (Perilau Hidup Bersih dan Sehat) di Era New Normal. SENAM : Prosiding seminar Nasional Abdimas Ma Chung, pp. 301-311. Malang, Indonesia.

Germas NTB (Gerakan Masyarakat Hidup Sehat Provinsi Nusa Tenggara Barat). 2021. http://corona.ntbprov.go.id.

Mahendra, A U., et al. 2020. Penyemprotan Disinfektan dan Pembagian Alat Kesehatan (Masker) Sebagai Upaya Mahasiswa KKN BMC UNNES 2020 dalam Pencegahan Penyebaran Covid-19 di Kabupaten Demak. Abdima: Artikel Pengabdian Masyarakat Universitas negeri Semarang, pp. 1-8. Semarang, Indonesia.

Mailani, F., et al. 2020. Edukasi PHBS (Perilaku Hidup Bersih dan Sehat), dan Social/Physical Distancing sebagai Upaya Pencegahan Penularan Virus Corona (Covid-19) pada Keluarga Pra Sejahtera. Jurnal Ilmiah Pengembangan dan Ipteks: Warta Pengabdian Andalas, 27 (3), 226-234. doi: https://doi.org/10.25077/jwa.27.3.226-234.2020

Marwang, S \& Sudirman, J. 2020. Upaya Peningkatan Pengetahuan Tentang Pencegahan Covid19 dengan Perilau Hidup Bersih, Sehat dan Gizi Seimbang di Panti Asuhan. Jurnal Pengabdian Nasional (JPN) Indonesia, 1 (2), 47-50. doi: https://doi.org/10.35870/jpni.v1i2.15

Nurfadillah, A R. 2020. Perilaku Hidup Bersih dan Sehat di Sekolah pada Masa Adaptasi Kebiasaan Baru (New Normal). Jurnal Pengabdian Kesehatan Masyarakat (JPMK), 1 (1), 1-6. doi: https://doi.org/10.37905/.v1i1.7676

Sekeon, F M., Rumayar, A A., \& Tucunan, A A T. 2021. Gambaran Perilaku Masyarakat Terhadap Pencegahan Corona Virus Disease (Covid-19) di Lingkungan III Kelurahan Tingkulu Kota Manado. Junal KESMAS: Jurnal Kesehatan Masyarakat Universitas San Ratulagi, 10 (1), 105-111. 